abstractions tends to melt in the face of the evidence they themselves have helped collect. This allows the class to move directly to the more interesting questions of the causes and effects of the relationships they find.

Finally, I have found that this series of projects makes the classroom experience much more productive and enjoyable for the instructor as well. First, there is the satisfaction of presiding over an active and interested cadre of scholars, as opposed to force-feeding information to reluctant undergraduates. Further, because the data these students bring in vary from semester to semester (as the members who are studied vary), the instructor never knows exactly what points will be made in discussion. Certainly, some results are more predictable than others, but there is always the random component of the processes that keeps the course fresh even after many times through it. I also enjoy not having to read 35 identical papers at the end of the semester. Each District-D.C. Connection paper is unique, because each member and district is unique. And along the way, each semester I learn a great deal about at least a half dozen members of the U.S. House with whom I am unfamiliar.

In sum, this project allows the instructor to meet the two-fold challenge outlined above: it provides students with a hands-on research experience, and it allows them to understand more deeply that most fascinating and inscrutable of institutions, the U.S. Congress.

\section{References}

Birnbaum, Jeffrey H., and Alan S. Murray. 1987. Showdown at Gucci Gulch. New York: Random House.

Cohen, Richard E. 1992. Washington at Work. New York: Macmillan.

Ehrenhalt, Alan. 1992. The United States of Ambition: Politicians, Power, and the Pursuit of Office. New York: Times Books.

Fenno, Richard F. 1978. Home Style: House Members in Their Districts. Boston: Little, Brown.

Mayhew, David R. 1974. Congress: The Electoral Connection. New Haven, CT: Yale University Press.

Miller, Warren E., Donald R. Kinder, Steven J. Rosenstone, and the National Election Studies. 1992. American National Election Study, 1990: Post-Election
Survey. Ann Arbor, MI: Inter-university Consortium for Political and Social Research.

Parker, Glenn R. 1989. "Members of Congress and Their Constituents: The HomeStyle Connection." In Congress Reconsidered, 4th ed., ed. Lawrence C. Dodd and Bruce I. Oppenheimer. Washington, DC: CQ Press.

Parker, Glenn R., and Roger H. Davidson. 1979. "Why Do Americans Love Their Congressmen So Much More Than Their Congress?" Legislative Studies Quarterly 4:52-61.

\section{About the Author \\ Christopher Z. Mooney}

Christopher Z.

Mooney is assistant professor of political science at West Virginia University. During 1993-95, he is visiting lecturer of government at the University of Essex, United Kingdom, where he teaches American politics and political methodology.

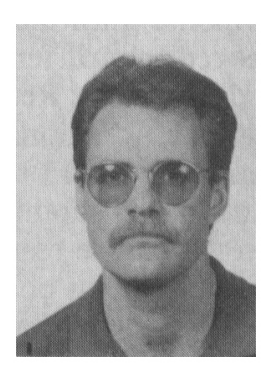

$$
\text { . }
$$

\title{
Using E-Mail to Enhance Class Participation*
}

\author{
Barbara Welling Hall, Earlham College
}

\begin{abstract}
Bluebook number 7. This student has never said a word in class. You barely remember what she looks like; her essay is . . . well organized, thoughtful, even witty in places. Too bad that she didn't speak up in class. Too bad that other class participants didn't hear what she had to say about the material. But can you do anything if she doesn't want to talk? This article describes one successful experience in using electronic communication to publicize the voices of otherwise silent students and, in general, enhance the equitability and liveliness of class participation. The particular course under investigation was a senior seminar in feminist international relations theory.

The discussion of participation in my syllabi encourages students to
\end{abstract}

synthesize the thoughts of one or more people by bringing together what has been said to form a new insight, conclusion, or question; to share materials (library books, newspaper and journal articles, current events, etc.) relevant to the course; and cooperate in creating a supportive atmosphere.

As a rule, I like to weight participation as a fairly hefty portion of the final course grade (at least 20\%) because I believe that the process of teaching and learning ought not to be exclusively "top-down," or what Paulo Freire (1968) would call "banking education" with the teacher making deposits into the students' supposedly blank minds. Feminist challenges to "banking education" have been significant (Belenky
1988; Harding 1991; Minnich 1990); for this reason, creating a conducive environment for active sharing of interpretations and experiences is an especially important goal for a course that is identified as "feminist."

This goal does not make evaluating participation any easier. If anything, the task of evaluating participation feels more difficult when more is expected than answering the teacher's questions in the teacher's presence.

Grading is, in some respects, inherently at odds with honoring the varied experience of different speakers. Those students who talk the most frequently and the most loudly rarely have the most insight. By the same token, those students who are most shy occasionally write elegant 
essays for my eyes only. Journal assignments keep me in close contact with quieter students, but, at least in my classes, there has been little interaction among students about journals.

I understand that there are many reasons beyond shyness or lack of confidence why students are quiet in class discussions. Those students who are familiar with the texts may well remain silent in class because they are unwilling to interrupt or, alternatively, the noise and pace of a class may prevent students from gathering together their thoughts for a coherent response until the conversation has moved to a different point.

In Feminist Readings in International Relations, an upper-level seminar with 13 students, I required students to submit weekly reflections on the course readings to an electronic bulletin board. In so doing, I was hoping to transcend some of these perennial problems with participation, to eventually create a jointly produced text for discussion purposes, and to further my own skills as an electronic communicator. I was hoping to discover and implement an appropriately feminist pedagogy in a class devoted to feminist content. $^{1}$

\section{Implementation}

My original idea was to establish an e-mail account for each of the students in the seminar, but in consultation with Earlham's VAX operators, we expanded the notion by using the NEWS electronic bulletin board and setting up a courserestricted newsgroup for the term. The NEWS utility on the VAX has several advantages over MAIL. First, students have limited space in their computer accounts and NEWS on the electronic bulletin board takes up less room on a student's individual VAX account than MAIL does. A second advantage of NEWS is that it is possible for a reader to follow-up a previous posting and for all readers to read through all follow-ups without necessarily reading everything extraneous in between.

One of my favorite features of NEWS is that writers may choose to CANCEL a message that they have posted. Such retractions are not possible with DEC/VMS MAIL. Finally, it is possible for students using NEWS to send private messages via the MAIL utility to a single reader.

In setting up the newsgroup for my class, I requested and received two irregular exceptions to standard newsgroup operating procedures. As course instructor, I acquired supervisor privileges, enabling me to delete any posted message and to add or delete members from the newsgroup. The newsgroup, as stated above, was readable only by students enrolled in Feminist Readings in International Relations. The second exception to standard operating procedure was that all messages posted to the newsgroup remained in the system for the duration of the course (unless deleted by the sender or supervisor). Normally, newsgroup messages remain on the bulletin board for a period of about three days.

Members of Earlham's computing staff introduced NEWS and the course-specific newsgroup to seminar students on the first day of the term in a PC lab during the second hour of a two-hour class. College computing staff demonstrated how to enter the newsgroup and how to post and read messages. During the term, I generated short writing assignments, but responses to my questions were not the most rewarding result in the use of NEWS.

\section{Results of Using the Newsgroup}

My primary intention in establishing the newsgroup was to provide a public voice for those students who rarely spoke in class. This, in fact, turned out to be the greatest success of the experiment. Quiet students used the newsgroup disproportionately more often than other students.

Here is what one quiet, but articulate, student wrote about her experience:

E-mail made me more comfortable about sharing my thoughts and impressions with others. It helped me to see how other people wrote, what they wrote about. . . . I think that I matured and my ideas widened primarily as a result of having this exposure outside of the class. I think it allowed each of us to better explore and share with the rest of the class our different view points, our different histories, and our different areas of knowledge than an in-class discussion brought out. I also think that having the e-mail allows all of the people to contribute their ideas to the class rather than just the brave few who speak. I also think that the classroom atmosphere was more relaxed and supportive because of these outside connections.

Rather than having the e-mail initiate class discussions, the newsgroup more often provided a forum for those ideas that occur after the inspiring moment had passed. Students who thought of an important connection or an unaddressed question after class could provide or request feedback that would most likely have been lost by the next scheduled class period. How often do students enter into a class discussion drawing on observations made in the previous session? In my experience, this happens very rarely, but it happened quite often in the newsgroup.

For example,

I've been thinking a lot about Bryn's question of how this all got started?? I mean, why did women assume a lesser position in society. I think a lot about Simone de Beauvoir who is quoted on page 27. With all these ties to the past, how can we change international relations now?

This excerpt from a student posting to the newsgroup provides some information about another significant contribution that e-mail made to the seminar. My overall impression is that students did a better job of reading and responding to the texts than they have in other courses I have taught. Unfortunately, at this point I don't have a "control group" either of a seminar that has read these texts without the newsgroup or a seminar that has read other texts with a newsgroup.

Here is another example of the kind of posting that showed up occasionally:

I found an interesting but short article in Radical America (Vol. 23, No. 4)it's the one on the shelves in Lilly entitled "Women in the Gulf" by Lynne Hanley, which discusses a bit about feminism and war. It's worth 
reading if you're looking for a justified study break.

In addition to reading and responding more often to works written by others, several students in the course felt that the presence of e-mail encouraged students to pay more attention to their peers.

As one student wrote in her course evaluation:

E-mail is a nice addition to class since, unfortunately, most students whom I've encountered show little interest in reading their classmates' papers. This is due, I think, to students being too lazy to read things written by people who they do not see as any higher than themselves on some imagined intellectual hierarchy, especially when they are long. With e-mail discussion, students have to listen and respond to the ideas of other students, something that many students may not view as necessarily important. To me, this is very important.

Along these lines, the newsgroup contained a heated, but civil, exchange between male and female students in the course about men, women, and the draft that was alluded to once or twice in class, but apparently felt safer in writing.

There are other respects in which e-mail appears to have provided a forum for writing that feels safe to students who lack confidence for various reasons. I believe that the exercise of seeing other students' writing in formative stages encouraged normally reticent students to write with more ease. Students noted that this writing felt more informal; there was less emphasis on spelling and more emphasis on stream of consciousness. A dyslexic student said that she appreciated the lack of pressure in informal writing. She also discovered that with her learning disabilities she felt more successful on a keyboard than she did in handwriting or speaking.

The following excerpt is drawn from a message posted by a student who had a 2.00 G.P.A. and continued to have difficulty in writing longer, traditional assignments. She was responding to Sandra Harding's assertion that "we are forced to remake science, but not under conditions of our own choosing."

Anything would be easier to remake under ideal conditions. I.R. and science do not stand alone in this case. Also, the notion of remaking under conditions of our choosing is irrelevant because it would require a universal agreement on the proper conditions and the changes that need to be made. Working within the system we already have to change and improve on I.R. seems like the only answer at present. To make significant changes in the way we study I.R. or the way it works does not necessarily require complete redoing, but rather reorganization of the ideals and priorities that we consider and study.

This is a significant contribution from a student who does weak work in other contexts.

My primary intention in establishing the newsgroup was to provide a public voice for those students who rarely spoke in class. This, in fact, turned out to be the greatest success of the experiment.

Lest the picture appear too rosy, there were difficulties in using the newsgroup. In the class of 13, two students hated computers in general and, therefore, hated the newsgroup. It took a few weeks to get the newsgroup really rolling because of some finickiness in the rules of sending and receiving messages.

Finally, there were some problems with access. At Earlham, there are only a few locations on campus at which students can access NEWS. Students needed to venture out of their dorms in order to post a contribution or read what others had to say. If these terminals were available in dormitories, I suspect that we would have had an even more lively exchange.

As I had planned, I based two class discussions on lengthy postings to the newsgroup. Surprisingly, this felt rather artificial to all of usmore like rehashing a discussion that had already taken place than discussing a new text hot off the press.

\section{Modifications for the Future}

Given the positive experience outlined above, I hope to replicate and improve upon this pedagogical technique in future classes. There are several relatively easy, and other more complicated, modifications that I hope to make:

1. Provide a tutor in the first week or two of the term to provide supplementary instruction on the use of NEWS. Although the computing staff was available to help, students are more accustomed to request help from tutors for course-specific assignments.

2. In order to get the ball rolling in the first few weeks of the term at least, assign students to take turns in generating questions or comments for the newsgroup.

3. Expand the use of the coursespecific newsgroup to a much larger class, e.g., 100 students. On the downside, such a newsgroup would be much more difficult to supervise. On the upside, students in such large classes have very few opportunities for interactions with fellow students.

4. Expand the use of the coursespecific newsgroup beyond the walls of Earlham. Most colleges and universities in the country have access to newsgroups through USENET. Although there are hundreds of debate-oriented newsgroups that focus on social and political issues without resolution, these do not have moderators and are, in the cases that I am familiar with, not based on common discussion of texts other than current events periodicals. Setting up a USENET newsgroup with a fellow faculty member teaching a similar course would expand the range of ideas to which our students are exposed. At the same time, a shared daily venue of process and content could go a long way toward relieving feelings of isolation experienced by faculty members who are teaching off the beaten track.

\section{Is This Feminist Pedagogy?}

Using e-mail to teach feminist readings in international relations worked better than many other techniques that I have tried to use to enhance active participation in courses. E-mail isn't the perfect tool 
of egalitarian education. By definition I have more access to computer:i and computing staff than my students do. Nonetheless, one of the consequences of the newsgroup was that in these out-of-class discussions, my words looked no different than anyone else's. The lasting results of the experiment are that silent students "spoke"; students paid respectful and constructive attention to each other's comments; and we explored lacunae in the discipline in an interactive fashion that permitted time for digestion and reflection. These are at least partial indicators of successful pedagogy in feminist International Relations.

\section{Notes}

*The author wishes to thank Hayward Alker, M.I.T. Political Science Department; Dan Meerson, Earlham College English
Department; Spike Peterson, University of Arizona Political Science Department; and Linda Racioppi, James Madison College of Michigan State University for their attentive comments; and special thanks to the students of PS 75 .

1. The texts for the course included du Plessix Gray (1990); Elshtain (1987); Enloe (1990); Grant and Newland (1991); and Harding (1991).

\section{References}

Belenky, Mary F., et al. 1988. Women's Ways of Knowing: The Development of Self, Voice, and Mind. New York: Basic Books.

du Plessix Gray, Francine. 1990. Soviet Women: Walking the Tightrope. New York: Doubleday.

Enloe, Cynthia. 1990. Bananas, Beaches, and Bases: Making Feminist Sense of International Politics. Berkeley: University of California Press.

Elshtain, Jean Bethke. 1987. Women and War. New York: Basic Books.

Freire, Paulo. 1970. Pedagogy of the Oppressed. New York: Continuum.
Grant, Rebecca, and Kathleen Newland. 1991. Gender and International Relations. Bloomington: Indiana University Press.

Harding, Sandra. 1991. Whose Science? Whose Knowledge? Ithaca: Cornell University Press.

Minnich, Elizabeth. 1990. Transforming Knowledge. Philadelphia: Temple University Press.

\section{About the Author \\ Barbara Welling Hall \\ Barbara Welling \\ Hall is associate pro- fessor of politics at \\ Earlham College. She is a post-Soviet specialist studying feminist approaches to international rela- tions theory, and she would be happy to \\ hear from colleagues on the subject of this article. Her e-mail address is WELLINGH@- YANG.EARLHAM.EDU.}

\title{
Capitalism and Democracy: A Play
}

\author{
Delmer Lonowski, South Dakota State University
}

There are a variety of ways to present the material in a political science class. One that is not often considered is the use of play-acting. Creating a play to present the material is relatively simple as will be demonstrated below.

In teaching a course on Russian politics, I felt that there were lessons to be learned from contrasting the reform experiences of the Chinese prior to Tiananmen Square to those experienced by the Soviet Union under glasnost and perestroika. These two events raise serious questions about the relationship of democracy to capitalism. Therefore, I was pleased to find Gabriel Almond's (1991) article on this relationship. My initial presentation in the fall of 1991 was a lecture based on the article. This fall, I found a new approach that may be more effective. It involved transforming Almond's article into a play, which the class then performed.

This method of presentation is recommended by Georgi Lozanov. Lozanov (1978, 256-57, 261-62) argues for attempting to reach not only the student's conscious level but also the unconscious and paraconscious levels as well. He suggests that these different levels can be accessed through three different means. First, by psychological means that involve both emotional stimulus and peripheral perceptions. This extends the scope of the assimilated material in the long-term memory. The second means is the didactic in which the instructor attempts to overcome the limitations of shortterm memory through generalization and the enlargement of perspectives. Generalization makes it possible to overcome the limitations of shortterm memory, while enlarging the perspective provides the student with an overall view of the material to be studied. Finally, the three levels of consciousness can be accessed by the introduction of various art forms, such as music, literature, and acting into the teaching and learning process. In doing so, the instructor creates not only a pleasant atmosphere but facilitates the student in his or her efforts to receive, memorize, and understand the information being presented.

The evidence that Lozanov (1978, 264-65) reports from studies using these methods is impressive. In one study of instruction in mathematics, in the pre-test, $57 \%$ obtained the correct answer. Following instruction with these methods, $74 \%$ of the students obtained the right answer. A second study utilized the method to teach English. The pre-test obtained $4.9 \%$ correct answers, the post-test, $13.5 \%$. Even more striking is the fact that without the students having had an opportunity to do any homework, a follow-up test was given the next day which obtained $23.7 \%$ correct answers. The differences between the tests in both studies were statistically significant $(p>0.001)$.

It was on the basis of Lozanov's 